\title{
Petrology and Geochemistry of the Ruby Slipper Lamproite, Western Montana: A Leucite-Bearing, Ultrapotassic Magma in an Eocene Continental Arc
}

Irving, Anthony J. and Kuehner, Scott M.

Dept. of Geological Sciences, University of Washington, Seattle, WA 98195, USA (irving@geology.washington.edu)

Although the most common tectonic setting for lamproites worldwide is stable cratons (Mitchell and Bergman, 1991), lamproitic magmas are known also from modern and ancient subduction settings (e.g., Kamchatka, Italy, Spain, Colorado - Seliverstov et al., 1994; Conticelli and Peccerillo, 1992; Venturelli et al., 1984; Thompson et al., 1997). We report here another occurrence of a lamproite plug spatially and temporally associated with rhyolites, andesites, shoshonitic basalts and minettes in an Eocene continental arc complex in western Montana, which may have important implications for the genesis of lamproitic magmas. Distinctive features of the Ruby Slipper lamproite include the preservation of unaltered leucite, the presence of accessory pyrochlore, relative depletions in $\mathrm{Ti}, \mathrm{Nb}$ and $\mathrm{Ta}$ typical of arc magmas, and similarities in $\mathrm{Sr}-\mathrm{Nd}-\mathrm{Pb}$ isotopic compositions with the younger Leucite Hills and Smoky Butte lamproites.

\section{Geologic Setting and Age}

The Ruby Slipper lamproite, located within the Great Falls tectonic zone on the northwestern margin of the Wyoming Craton, forms a roughly circular plug about $500 \mathrm{~m}$ in diameter. A grey, finer grained, sparsely mica-phyric border phase surrounds a greenish, coarser grained interior phase. Lithic, volcaniclastic(?) breccias containing clasts of basalt, rhyolite and minette crop out on the east side of the plug and were encountered to a depth of $130 \mathrm{~m}$ in drill holes on the west margin (Figures 1 and 2). Micas from the border and interior lamproites produced climbing ${ }^{40} \mathrm{Ar} /{ }^{39} \mathrm{Ar}$ spectra that yield high temperature plateau ages of $48.0 \pm 0.1$ and $48.4 \pm 0.1 \mathrm{Ma}$, respectively; mica from a minette located $7 \mathrm{~km}$ away gave a plateau age of $48.4 \pm 0.2 \mathrm{Ma}$. The radiometric ages reinforce the field relationships and imply that these potassic magmas were emplaced $48 \mathrm{Ma}$ ago at shallow depths into a slightly older (49.3-49.7 Ma) subaerial basalt-rhyolite-andesite-latite lava flow/tuff sequence.

\section{Petrography and Mineral Compositions}

The lamproites consist of phlogopite, diopside, fluorapatite, magnesio-katophorite, ferrian sanidine, leucite and ilmenite, with accesory niobian pyrochlore, Ti-maghemite, baddeleyite and monazite. Phlogopite phenocrysts are magnesian ( $m g$ 0.84-0.89) with high F contents (2.9-4 wt.\%) and relatively low $\mathrm{BaO}$ contents (0.6-1.2 wt.\%). In comparison to those in Leucite Hills lamproites, the Ruby Slipper phlogopites have similar $\mathrm{Al}_{2} \mathrm{O}_{3}$ contents (11.7-13.4 wt.\%) but higher $\mathrm{TiO}_{2}$ contents (3.5-4.8 wt.\%). Mica phenocryst rims and groundmass oikocrysts display characteristic lamproite zoning trends (Figure 3) towards lower $m g$ (0.61-0.74) and lower $\mathrm{Al}_{2} \mathrm{O}_{3}$ (8.7-11.2 wt.\%). Clinopyroxene microphenocryst cores are diopside ( $m g$ 0.84-0.89; $\mathrm{Al}_{2} \mathrm{O}_{3}$ 0.4-0.8 wt.\%), with zoning (Figure 4) towards aegirine-rich rims containing appreciable $\mathrm{Na}_{2} \mathrm{O}$ (up to 10 wt.\%), $\mathrm{FeO}$ (up to 15.9 wt.\%) and $\mathrm{ZrO}_{2}$ (up to.4.2 wt.\%). Amphiboles are magnesio-katophorite ( $m g$ 0.75-0.82) with high F contents (2.0-2.8 wt.\%), and differ from most other lamproite amphiboles in having slightly higher $\mathrm{Al}_{2} \mathrm{O}_{3}$ (1.0-2.3 wt.\%) and $\mathrm{Na}_{2} \mathrm{O}\left(6.0-7.6\right.$ wt.\%) but lower $\mathrm{TiO}_{2}$ (2.6-5.2 wt.\%). The feldspar is ferrian sanidine (1.3-3.3 wt.\% $\mathrm{Fe}_{2} \mathrm{O}_{3}$ ) enriched in $\mathrm{Na}_{2} \mathrm{O}(0.9-2.3$ wt.\%) and $\mathrm{BaO}$ (1.7-5.4 wt.\%). Leucite (the oldest occurrence of which we are aware) contains 1.4-1.9 wt. $\% \mathrm{Fe}_{2} \mathrm{O}_{3}$ and shows nonstoichiometric enrichment in $\mathrm{Si}$ (2.01-2.03 atoms per formula unit). 


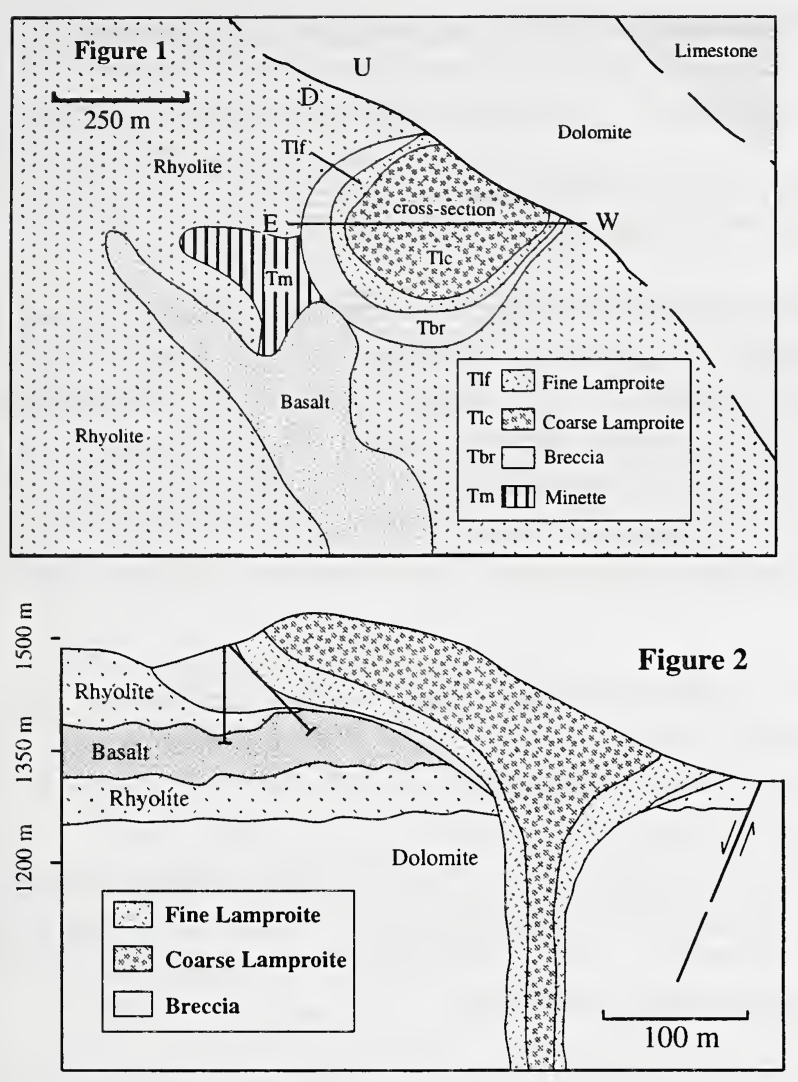

Table 1 Lamproite (border phase)

$\begin{array}{lrlr}\mathrm{SiO}_{2} & 47.36 & \mathrm{SrO} & 0.29 \\ \mathrm{TiO}_{2} & 2.38 & \mathrm{Na}_{2} \mathrm{O} & 1.87 \\ \mathrm{Al}_{2} \mathrm{O}_{3} & 10.45 & \mathrm{~K}_{2} \mathrm{O} & 7.72 \\ \mathrm{Cr}_{2} \mathrm{O}_{3} & 0.03 & \mathrm{P}_{2} \mathrm{O}_{5} & 2.86 \\ \mathrm{Fe}_{2} \mathrm{O}_{3} & 4.80 & \mathrm{ZrO}_{2} & 0.22 \\ \mathrm{FeO} & 2.89 & \mathrm{H}_{2} \mathrm{O}+ & 1.69 \\ \mathrm{MnO} & 0.12 & \mathrm{CO}_{2} & 0.17 \\ \mathrm{MgO} & 7.11 & \mathrm{~F} & 0.40 \\ \mathrm{CaO} & 8.37 & \mathrm{SUM} & 99.56 \\ \mathrm{BaO} & 1.00 & & \end{array}$

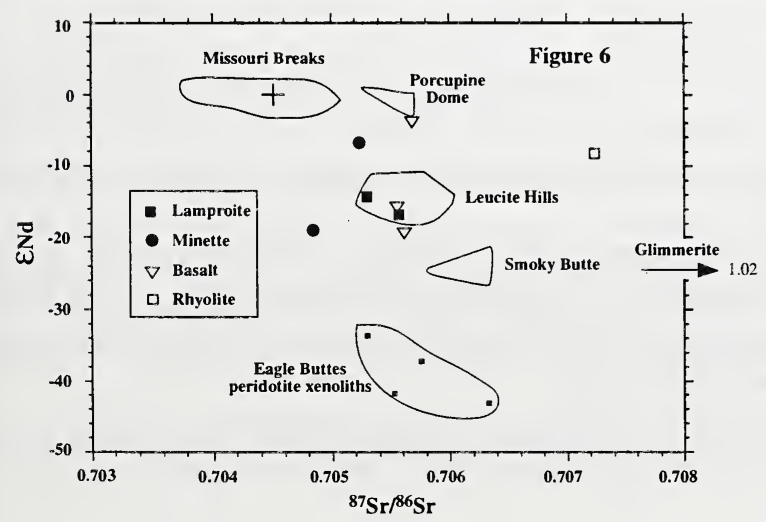

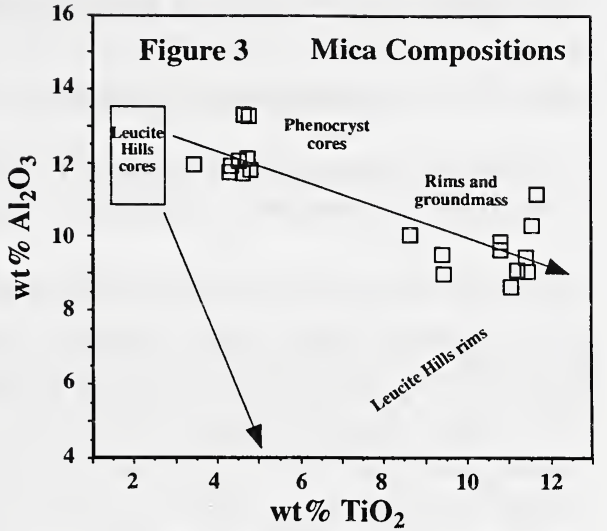
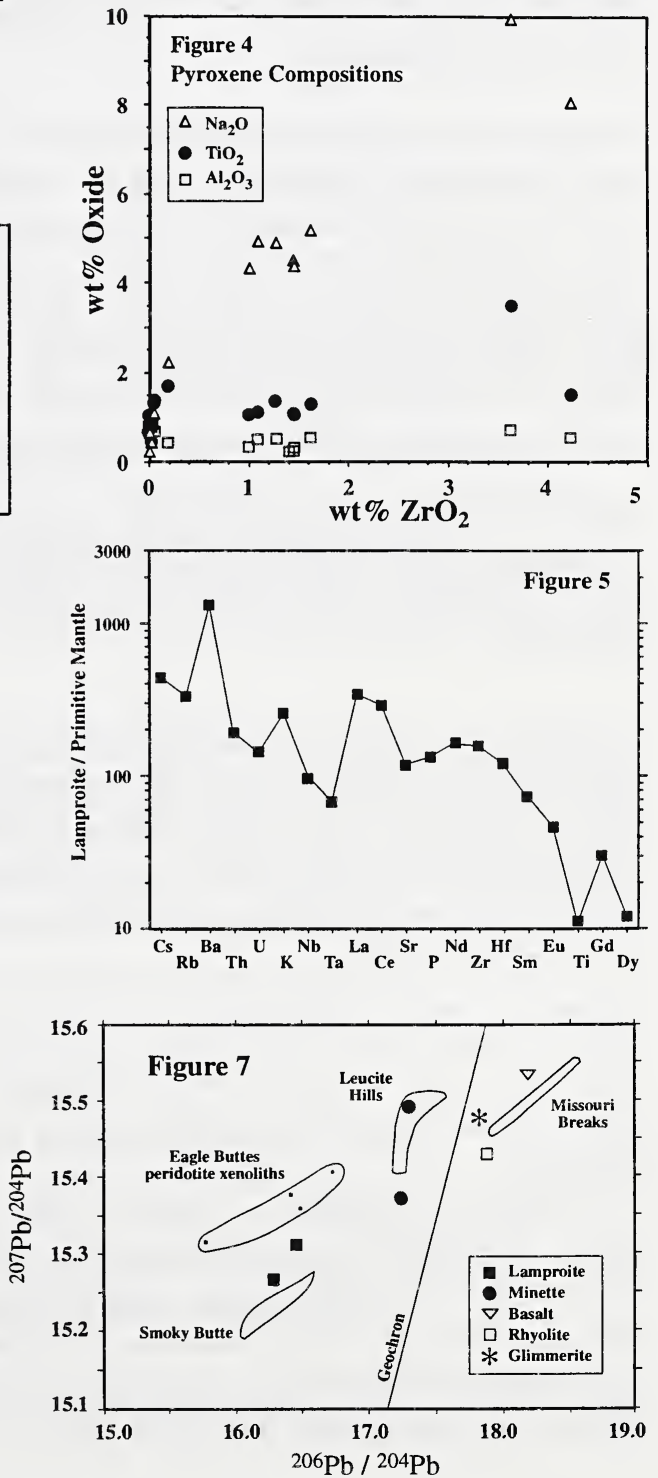